\title{
Decomposition cross-correlation for analysis of collagen matrix deformation by single smooth muscle cells
}

Jeroen van den Akker · Adrian Pistea •

Erik N. T. P. Bakker · Ed VanBavel

Published online: 17 April 2008

(C) The Author(s) 2008

Erratum to: Med Biol Eng Comput

\section{DOI 10.1007/s11517-008-0325-z}

Unfortunately, the Acknowledgment was missing. The correct Acknowledgment is given below.
Jeroen van den Akker and Erik Bakker were supported by grants 2005B080 and 2001D038 from the Netherlands Heart Foundation.

The online version of the original article can be found under doi:10.1007/s11517-008-0325-z.

J. van den Akker · A. Pistea - E. N. T. P. Bakker .

E. VanBavel $(\bowtie)$

Department of Medical Physics, Academic Medical Center,

University of Amsterdam, P.O. Box 22700,

1100 DE Amsterdam, The Netherlands

e-mail: e.vanbavel@amc.uva.nl

J. van den Akker

e-mail: jeroenvandenakker@amc.uva.nl 